\title{
HOLLAND AND THE BRITISH ISLES
}

\section{ENGLAND}

The Science and Engineering Research Council (SERC) has created a Biotechnology Directorate to coordinate research and training programs in biotechnology and to promote biotechnological research through partnerships between universities, polytechnics, and industry. SERC hopes to increase its research support in the fields of fermentation, enzyme and immobilized cell technology, separation and concentration technology, product processing, waste treatment and by-product utilization, and feedstock development for biological processes.

Leicester University in Leicestershire has been recognized by the government as a center of excellence in biotechnology. With support from the County Council, the university established the Leicester Biocentre for research. The university's industrial partners in this venture include John Brown Engineering, Dalgety Spillers Ltd., Gallagher L.td., and Whitbread \& Co. PLC. The biocentre will offer consultancy services, contract research facilities, and courses and seminars in an effort to promote technology transfer between the university and industry. The Core Research Programme of the Biocentre is as follows: molecular biology of yeast plasmid replication; plant gene expression in yeast and bacteria; and protein segregation in yeast.

The Liverpool government has taken steps to strengthen the region's biotechnology industry base, including the con- struction of a $£ 9$-million high technology park in the heart of the city. The park is linked to Liverpool University and Liverpool Polytechnic. The former's collaborations with local chemical and pharmaceutical companies has already led to the formation of two companies that supply materials and services to the nuclear biology industry.

The North of England boasts biotechnological research activities at Newcastle University, Durham Univerity, Newcastle Polytechnic, Sunderland Polytechnic, and Teesside Polytechnic. The five institutions have joined to create a program of Higher Educational Support for Industry in the North.

The North East Biotechnology Centre, a consortium of Teesside and Sunderland Polytechnics was developed to promote biotechnology. Designated as a national Centre for Development, the organization oversees biotechnology activity at the two schools and biotechnology education in the region.

The Yorkshire and Humberside Development Association is actively promoting the health care and biotechnology industries. The region is home to about 120 companies that emphasize pharmaceuticals, hospital and medical suplies, dental equipment, and biotechnology.

\section{IRELAND}

The National Board of Science and Technology (NBST) is a state-sponsored agency that advises the Irish government on matters of science and technology, and funds research in universities as well as joint university-industry projects. NBST's three priority fields are engineering and materials, information technology, and biotechnology.

In association with the NBST and the Industrial Development Authority (IDA), the Irish government is creating a $\$ 10$ million fund to support the establishment of four centers of excellence in biotechnology. The center's areas of emphasis will be immunodiagnostics and mammalian reproduction of cells, food and plant technology, molecular genetics, and microbial fermentation. The centers will be based in universities, supported with funds from industry and the government, and eventually becoming self- financing through contract research.

Through the Cooperative R\&D Grant Program, NBST and IDA cosponsor up to 50 percent of the cost of cooperative university- industry projects. The Strategic Research Grant Program supports basic and applied research programs in academic institutions. In addition, the IDA sponsors international programs aimed at obtaining research contracts for scientists in Irish universities and attracting foreign industry.

The Irish government offers a variety of tax and other financial incentives to entice new businesses, including a maximum 10 percent tax on corporate profits through the year 2000.

\section{NETHERLANDS}

The Dutch government is taking an active role in stimulating the development of the biotechnology industry in the Netherlands. The government offers tax and other financial incentives to emerging biotechnology companies, including its $\$ 400$ million MIP Equity Fund. These incentives have already convinced Centocor and Molecular Genetics to establish operations in the Netherlands.

Other government initiatives include the Biotechnology Research and Feasibility Studies, in which companies can qualify for subsidies of up to 50 percent of their investments in basic research projects. The Innovation Stimulation Scheme enables firms to apply for subsidization of R\&D wage costs. Businesses can obtain government loans to support the development of new products, technologies, or services through the Technological Development Credits program. And High Technology Grants can total 20 percent of a firm's investments in fixed assets.

Biotechnological research in the Netherlands emphasizes human and veterinary health care, the food and beverage industry, and agricultural applications. Dutch companies active in these fields in clude Gist Brocades, Heineken, and Akzo-Pharma. In addition, the Netherlands Industrial Commission maintains three offices in the United States to assist American companies in entering Europe.

The biotechnology Innovation Research Programme, a joint effort of the Dutch government, industry, and academia, seeks to promote the application of research projects in academic institutions to aid the Dutch economy. 